\title{
ANÁLISE PETROGRÁFICA DOS IGNIMBRITOS BEM PRESERVADOS DA FORMAÇÃO CACHOEIRA DA ILHA, CENTRO-NORTE DO CRÁTON AMAZÔNICO, ESTADO DE RORAIMA
}

\author{
Nazaré Alves Barbosa ${ }^{1}$ \\ Hilberto de França Soares ${ }^{2}$ \\ Lorena Malta Feitoza ${ }^{3}$
}

\subsection{0/1980-8208/estudosgeologicos.v30n1p100-114}

${ }^{1}$ Mestra em Geologia, Universidade de Brasília - UnB, nazaresinzismundo@gmail.com. ${ }^{2}$ Graduado em Geologia, Universidade Federal de Roraima - UFRR, hillgeos@gmail.com.

${ }^{3}$ Docente do Departamento de Geologia, Universidade Federal de Roraima - UFRR, lorena.malta@ufrr.br.

\section{RESUMO}

A Formação Cachoeira da Ilha (FCI), localiza-se na porção centro-norte do Cráton Amazônico, nordeste de Roraima. É constituída por rochas ignimbríticas com cerca de 1990 Ma. As rochas piroclásticas ácidas na região do município de Amajari foram classificadas em ignimbritos: maciços, de moderado soldamento e reomórfico a partir das variações do grau no processo de soldagem, proporção e tipo de piroclastos e aspectos texturais. Os cristaloclastos são de quartzo, sanidina e plagioclásio e estão dispersos em matriz vitrofírica. Encontram-se geralmente com golfos de corrosão, denteados e intensamente sericitizados e/ou saussuritizados, evidenciando alteração hidrotermal de baixa temperatura. É possível distinguir ainda fragmentos líticos máficos, microporfiríticos e cognatos. .

Palavras chave: Vulcanismo, Paleoproterozoico, Escudo das Guianas.

\begin{abstract}
The Cachoeira da Ilha Formation (FCI) is located in the north central portion of the Amazonian Craton, northeast of Roraima. It is found by ignimbritic rocks with about $1990 \mathrm{Ma}$. Acid pyroclastic rocks in the region of the municipality of Amajari were classified as ignimbrites: solid, moderately welded and rheomorphic from variations in the degree in the welding process, proportion and type of pyroclasts and textural aspects. The crystalloclasts are made of quartz, sanidine and plagioclase and are dispersed in a glass-matrix. They are usually found with corrosion, dentate and intensely sericitized and/or saussuritized gulfs, showing low temperature hydrothermal alteration. It is also possible to distinguish mafic, microporphyritic and cognate lithitic fragments.
\end{abstract}

Keywords: Volcanism, Paleoproterozoic, Guyana Shield.

\section{INTRODUÇÃOO}

A Formação Cachoeira da Ilha (FCI) engloba rochas vulcânicas e subvulcânicas ácidas com afinidade geoquímica tipo-A, dispostas na porção nordeste do estado de Roraima (CPRM, 2010). Essas rochas juntamente com os granitoides das Suítes Pedra Pintada e Aricamã e as rochas vulcânicas do Grupo 
Surumu, compõem um cenário de ambiente pós-orogênico com fusão parcial de material Transamazônico (CPRM, 2010).

Esta unidade foi inicialmente caracterizada durante o mapeamento geológico da Folha Vila de Tepequém NA.20-X-A-11, sendo a única referência até o momento, em que tal diferenciação apoiou-se essencialmente, em critérios geoquímicos e aerogeofísicos (CPRM, 2010).

Este trabalho tem o propósito de apresentar os dados resultantes de investigação petrográfica detalhada dos ignimbritos com intuito de contribuir com o conhecimento geológico desta unidade, visto que em consequência da baixa densidade de dados ainda não foi possível realizar correlação com outras unidades vulcânicas presentes no Cráton Amazônico, pois não foram identificadas unidades com afinidade tipo-A e idade similar à da FCI.

\section{ÁREA DE ESTUDO}

A área de estudo é delimitada pelas coordenadas X: 645363 / Y: 441145 e X: 666515 / Y: 422540; situa-se a nordeste do estado de Roraima, noroeste da capital Boa Vista, integrando o município de Amajari, nordeste da Folha NA.20-X-A-III, sendo o rio Amajari a principal drenagem. As vias de acesso são pelas rodovias federal BR-174, sentido Boa Vista-Pacaraima, estadual RR-203 e municipal AMJ-010, além da vicinal Ouro verde (Fig. 1).

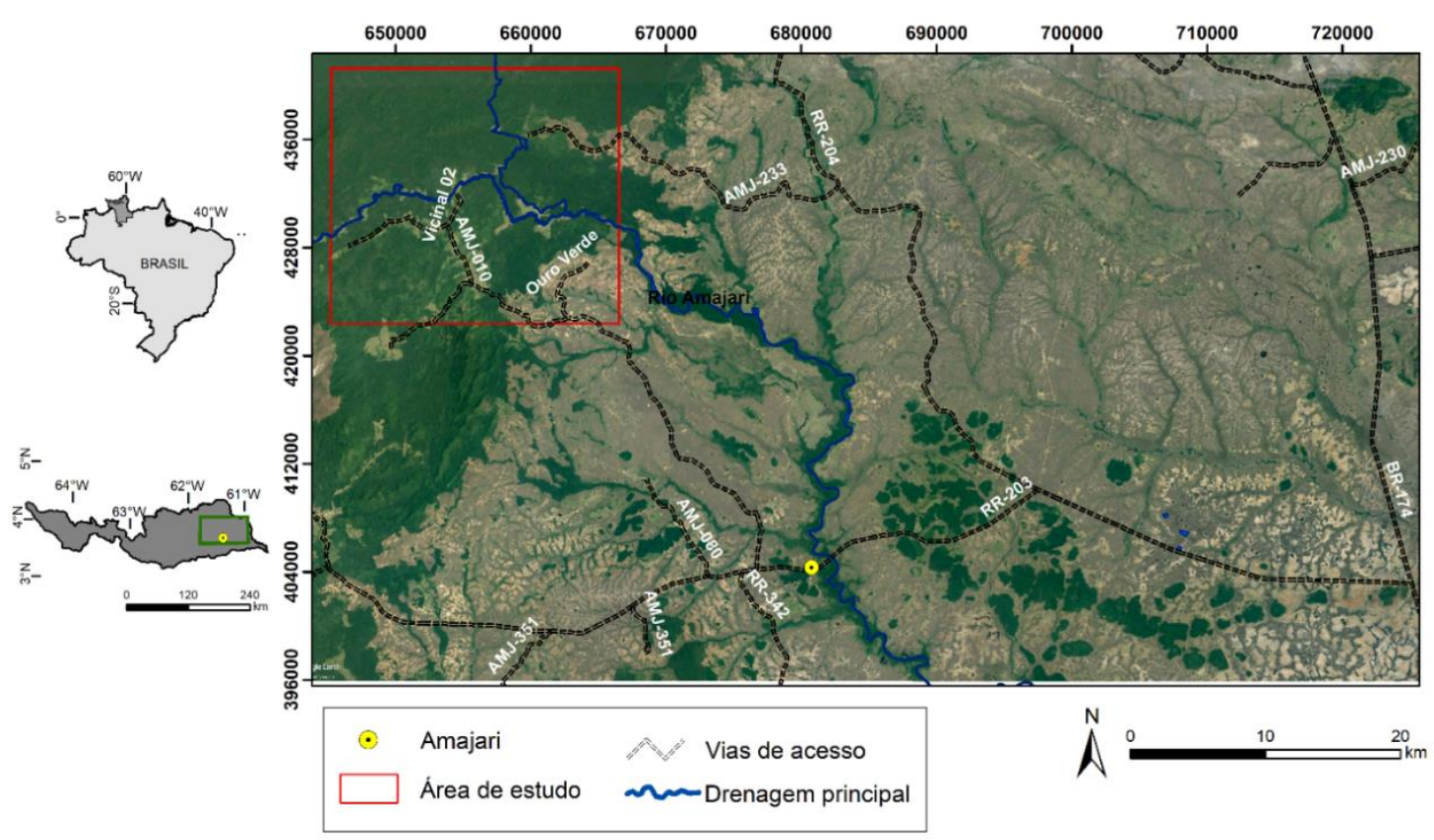

Figura 1 - Localização da área de estudo no nordeste de Roraima integrando o município de Amajari com suas principais drenagens e vias de acesso.

\section{GEOLOGIA REGIONAL}

O arcabouço geológico do estado de Roraima está inserido no norte do Cráton Amazônico e é dividido em quatro domínios litoestruturais: Guiana Central (NE-SW), Parima (NW-SE), Uatumã - Anauá (NW-SE e NE-SW) e
Surumu (WNW-ESE e E-W) (Reis e Fraga, 1998; Reis et al., 2003, 2004).

$$
\text { O Domínio Surumu (DS) }
$$
compreende rochas associadas ao vulcano-plutonismo Orocaima (1,961,98 Ga, Reis et al., 2003; 2,00-1,96 Ga, Fraga et al., 2017) incluídas no Grupo Surumu e na Formação Cachoeira da Ilha 
(CPRM, 2010). Além de apresentar distribuição para a Guiana (Formação Iwokrama, Reis et al., 2017), Venezuela (Grupo Cuchivero, Gibbs e Barron 1993) e Suriname (Formação Dalbana, Gibbs e Barron 1993) (Fig. 2A).

De forma geral, consistem em litotipos de natureza cálcio-alcalina de alto potássio, tipo-I, metaluminosas a peraluminosas (Bezerra, 2010) e a tipos de afinidade tipo-A, subalcalinas, transicionais entre metaluminosas $\mathrm{e}$ fracamente peraluminosas (CPRM, 2010).

A formação destas rochas é correlacionada a um cenário póscolisional ou tardi-orogênico, relacionado ao fim da Orogenia Transamazônica (CPRM, 2010), ou ao magmatismo de arco (Santos, 2003).

\section{GEOLOGIA LOCAL}

A individualização da Formação Cachoeira da Ilha (FCI) apoiou-se essencialmente em critérios geoquímicos e aerogeofísicos, em que o último distingue anomalias gamaespectrométricas significativas (CPRM, 2010).

Segundo CPRM (2010), a FCI engloba ignimbritos riolíticos dispostos sob a forma de corpos lenticulares e rochas subvulcânicas ácidas que ocorrem como diques cortando os vulcanitos do Grupo Surumu e os granitoides da Suíte Pedra Pintada (Fig. 2B).
Os ignimbritos são geralmente cinza escuros ou pretos, com ocorrências de variedades de cor carmim, vermelha, cinza clara e cinza rosada. São constituídos por fenocristais félsicos (1 a $5 \mathrm{~mm})$ e partículas de púmice $(15 \mathrm{~cm}$ de comprimento) (CPRM, 2010). Ainda segundo este trabalho, ocorrem ignimbritos pouco soldados com púmices bem preservados.

As rochas subvulcânicas são hololeucocráticas, em geral porfiríticas, avermelhadas ou róseas, raramente acinzentadas, correspondendo a álcalifeldspato-microgranitos, riolitos e micro-quartzo-sienitos (CPRM, 2010). Conforme CPRM (2010), estas rochas correspondem a riolitos subalcalinos, transicionais entre metaluminosos $\mathrm{e}$ fracamente peraluminosos, cujas características geoquímicas como os altos conteúdos em $\mathrm{SiO}_{2}$, álcalis $\mathrm{e}$ elementos HFS (high field strength) e ETR (elementos terras raras) leves indicam afinidade química com magmas do tipo-A.

Datação $\mathrm{Pb}-\mathrm{Pb}$ por evaporação em monocristais de zircão forneceu uma idade de $1986 \mathrm{Ma}$ para um ignimbrito desta unidade (CPRM, 2010). Embora, a FCI não apresente dados isotópicos SmNd, CPRM (2010) admite que a sua origem envolva a fusão de fontes crustais quartzo-feldspáticas de composição quartzo-diorítica a tonalítica ou granodiorítica. 


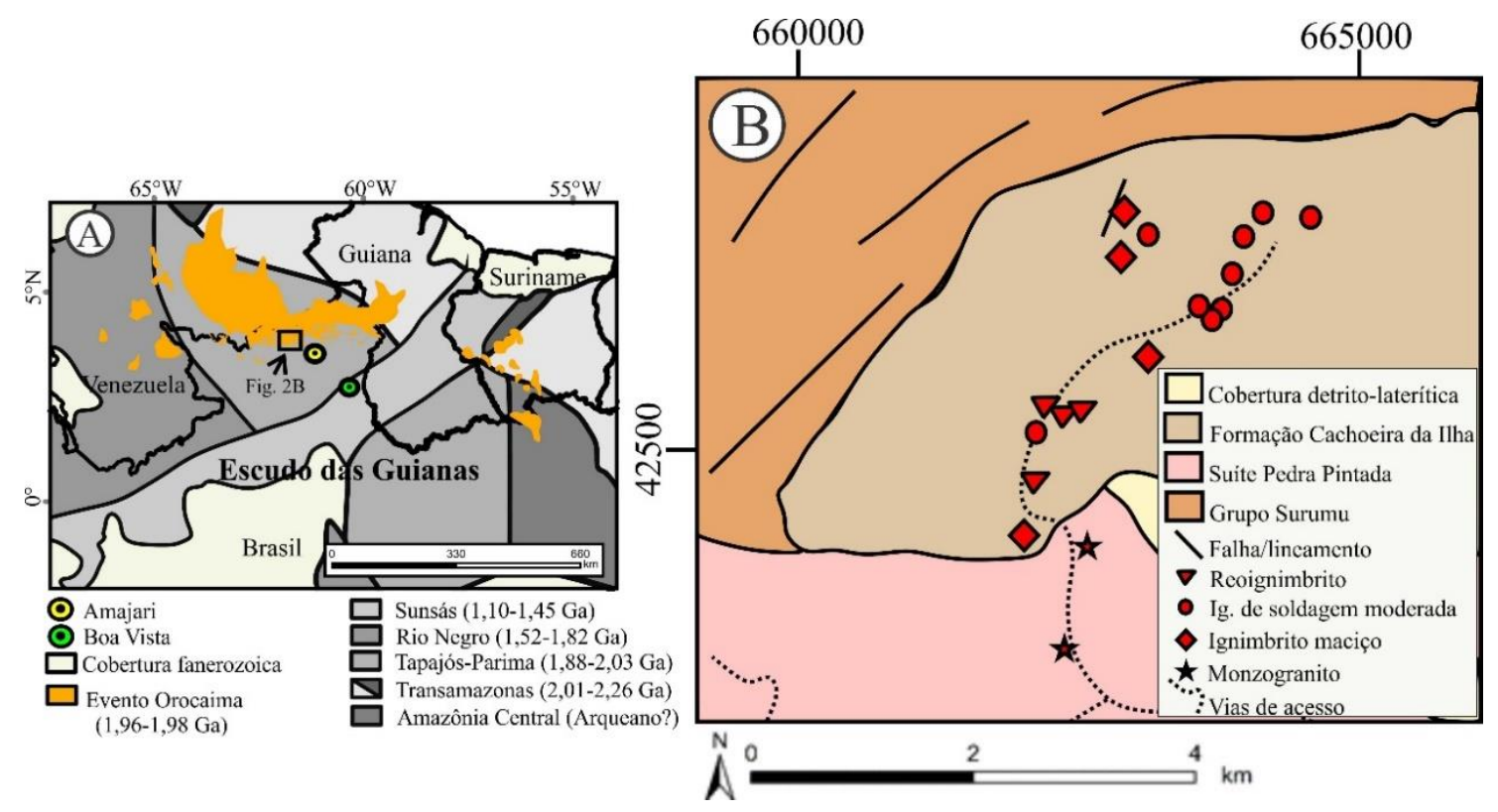

Figura 2 - A) Distribuição do vulcano-plutonismo no Escudo das Guianas, Cráton Amazônico. B) Mapa geológico da porção sudeste da Folha Vila de Tepequém, com as principais unidades litoestratigráficas aflorantes e pontos visitados, com destaque para os a diferenciação de ignimbritos (Modificado de CPRM, 2010).

Viana (2012) propõe com base em dados geoquímicos que os álcalifeldspato granitos da Suíte Intrusiva Saracura englobados na Suíte Aricamã por CPRM (2010), sejam os correspondentes intrusivos das rochas vulcânicas da Formação Cachoeira da Ilha, cujo magmatismo responsável pela geração destas rochas foi denominado por Viana (2012) de Magmatismo Areia Branca.

\section{METODOLOGIA}

A etapa de campo consistiu na coleta de amostras representativas de rochas ignimbríticas de áreas definidas em fase pré-campo. Foram visitados e descritos 23 afloramentos (Fig. 2B), totalizando 47 amostras coletadas para análise macroscópica, no qual 14 foram escolhidas para caracterização microscópica, com descrições acerca da composição mineralógica, textural e grau de alteração.

As descrições foram realizadas com base nos parâmetros definidos por Fisher (1966), Schmid (1981), McPhie et al. (1993) e Le Maitre (2002). A análise macroscópica foi efetuada no Laboratório de Mineralogia do Departamento de Geologia (IGEO/UFRR). A confecção das lâminas petrográficas delgadas polidas foi realizada no Laboratório de Laminação do Núcleo de Pesquisa Energética (NUPENERG/UFRR), cuja análise petrográfica ocorreu no Laboratório de Petrografia do Departamento de Geologia (IGEO/UFRR).

\section{APRESENTAÇÃO DOS RESULTADOS}

\section{Aspectos de campo}

As rochas ignimbríticas da FCI encontram-se, de maneira geral, dispostas na forma de blocos angulosos a subarredondados, rolados, centimétricos a decamétricos em meio à vegetação de savana arborizada, com árvores de médio porte, por vezes ombrófila aberta, relevo colinoso com ocorrência esporádica de blocos in situ (Figs. 3A-3B). 
O aspecto das rochas é de modo geral maciço. Mas algumas exposições manifestam evidente textura eutaxítica, por vezes ressaltadas na superfície das rochas. Destaca-se que os ignimbritos vítreos bandados apresentam-se expostos em forma de pináculos (Fig. $3 \mathrm{C})$.
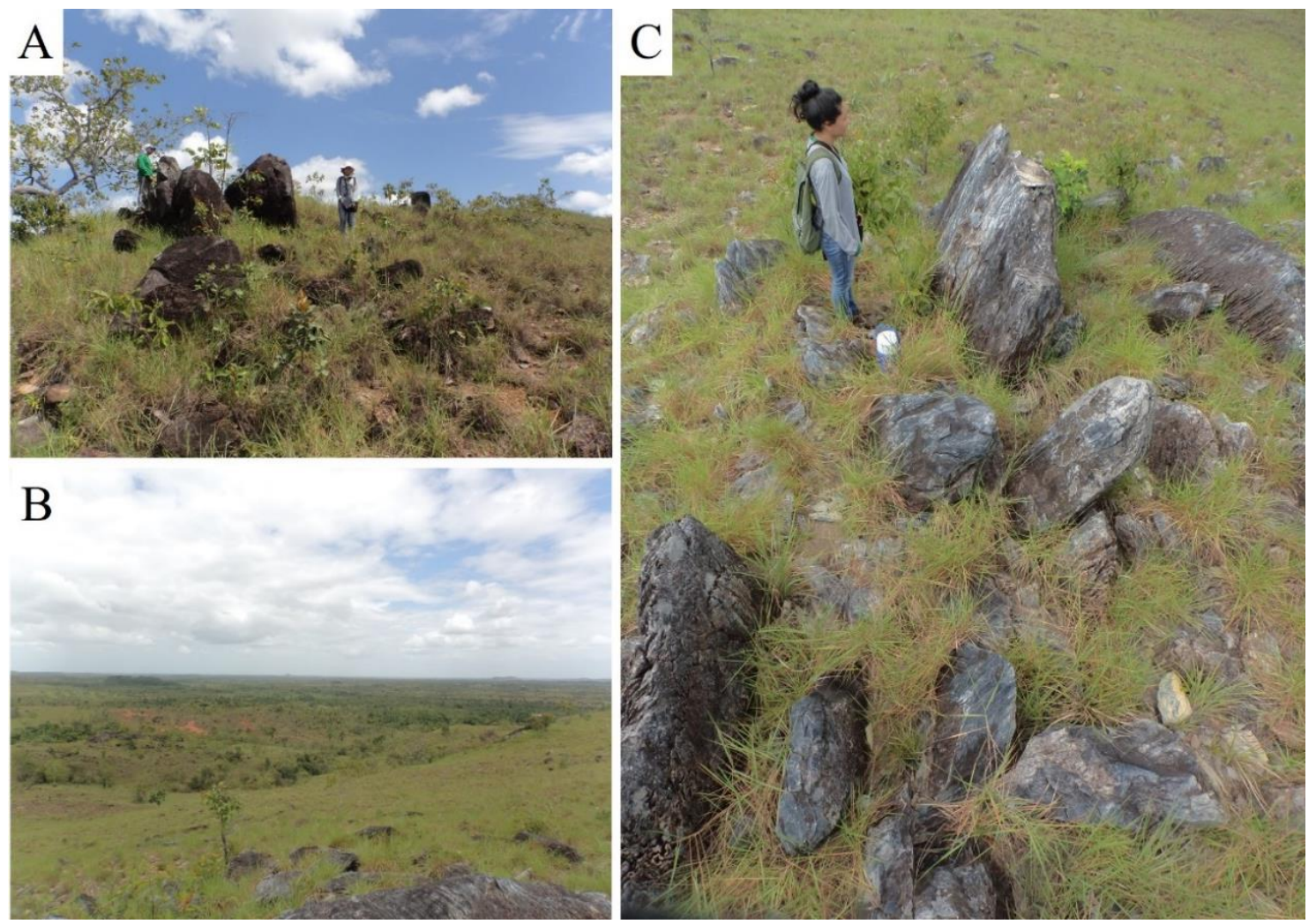

Figura 3 - A) Blocos subarredondados, rolados, centimétricos a métricos formando pequena colina. B) Forma geral de exposição dos ignimbritos formando relevo colinoso. C) Exposição em forma de pináculos verticais a subverticais.

\section{Aspectos macroscópicos}

Os ignimbritos apresentam cores que variam de preto a cinza escuro, ocorrendo ainda variedade de cor cinza rosado, sendo as duas primeiras predominantes na área de estudo (Figs. 4A-4C).

Estas rochas exibem grau de soldamento moderado a alto, são mal selecionadas e compostas por cristais de quartzo e feldspatos, fragmentos líticos máficos e vitroclastos, todos de granulometria cinza-lapilli e dispostos em uma matriz afanítica.

Nota-se textura eutaxítica evidenciada por porções vítreas alongadas e lenticulares que formam fiammes (Fig. D), bem como fragmentos pumíceos bem preservados com formas lenticulares e aspecto poroso (Fig. 4E). Destaca-se algumas porções com feições de coloração esbranquiçada no qual sugerese neste trabalho, que seria o possível registro de percolação de fluído com ocorrência de carbonatos (Fig. 4F). 


\section{ANÁLISE PETROGRÁFICA DOS IGNIMBRITOS BEM PRESERVADOS...}
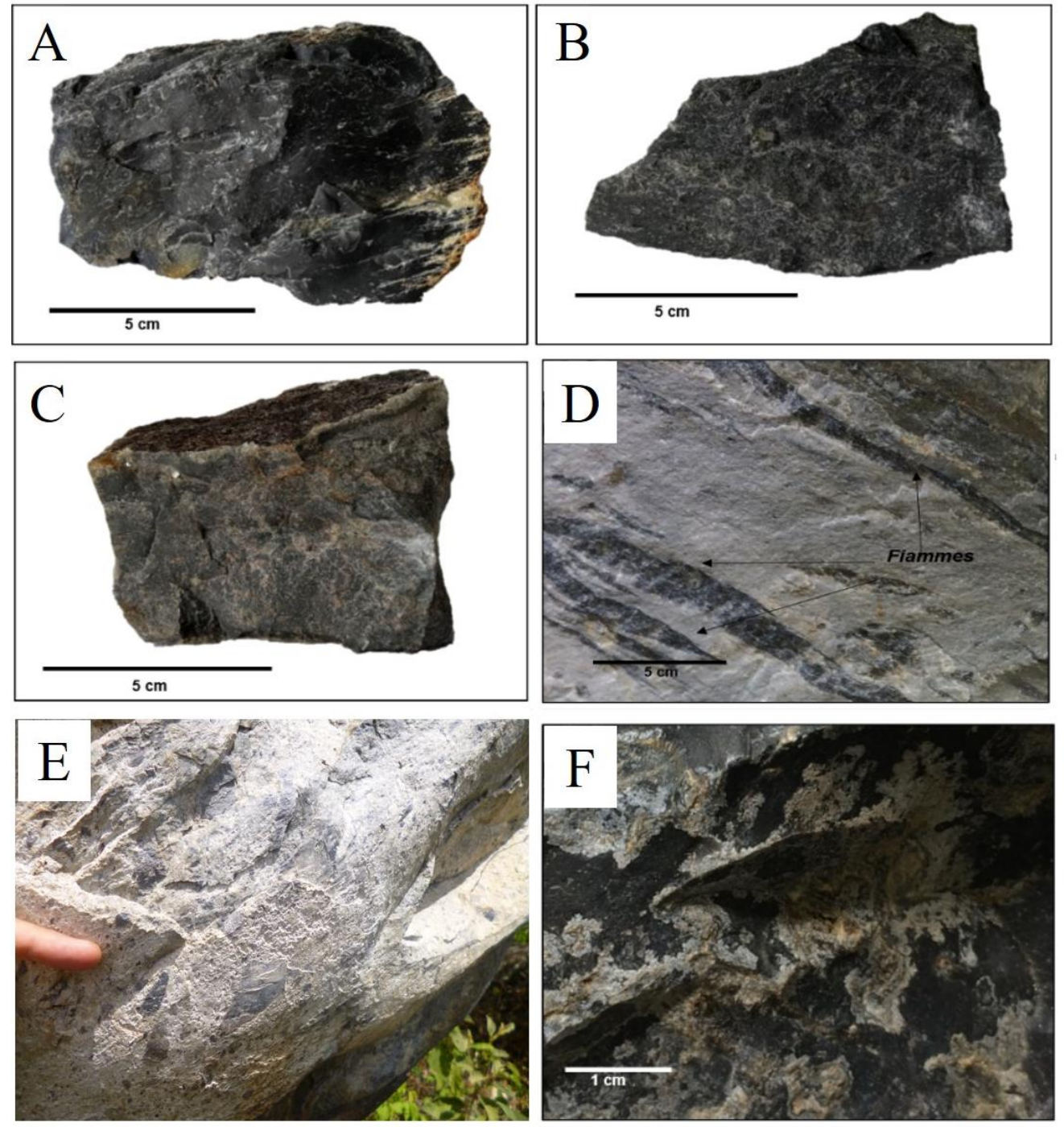

Figura 4 - A) Ignimbrito preto e vítreo. B) Ignimbrito cinza escuro. C) Ignimbrito cinza rosado. D) Fiammes evidenciando alto grau de soldagem. E) Vidro e púmice sem achatamento em ignimbrito maciço. F) Porção intensamente alterada em ignimbrito cinza escuro, porção esbranquiçada manifesta feições de percolação de fluído.

Os litoclastos máficos são preferencialmente subangulosos ocorrendo ainda sob formas subarredondadas e angulosas, com tamanho essencialmente lapilli de até 62 $\mathrm{mm}$. Exibem predominantemente textura afanítica dificultando a distinção e descrição macroscópica de seus constituintes (Fig. 5A). Quando possível, observa-se cristais de biotita, quartzo, plagioclásio e sulfetos.

Outra variação de litoclasto encontra-se restrita aos ignimbritos cinza rosados. São félsicos, angulosos, com tamanhos lapilli $(36 \mathrm{~mm})$ e cor rosa esbranquiçado, por vezes demonstramse esverdeados quando alterados. Exibem granulação fina, cuja constituição mineralógica consiste em quartzo, feldspato alcalino, plagioclásio e biotita. Destaca-se ainda, litoclasto anguloso, tamanho lapilli $(60 \mathrm{~mm})$, cuja composição e estrutura assemelham-se ao ignimbrito que exibe bandas vítreas (Fig. 5B).

Os fragmentos de vidro, quando não achatados, são angulosos, pretos ou cinza-escuros, com tamanhos de até 55 $\mathrm{mm}$, que por vezes incluem cristais de quartzo e feldspatos (Fig. 5C). 

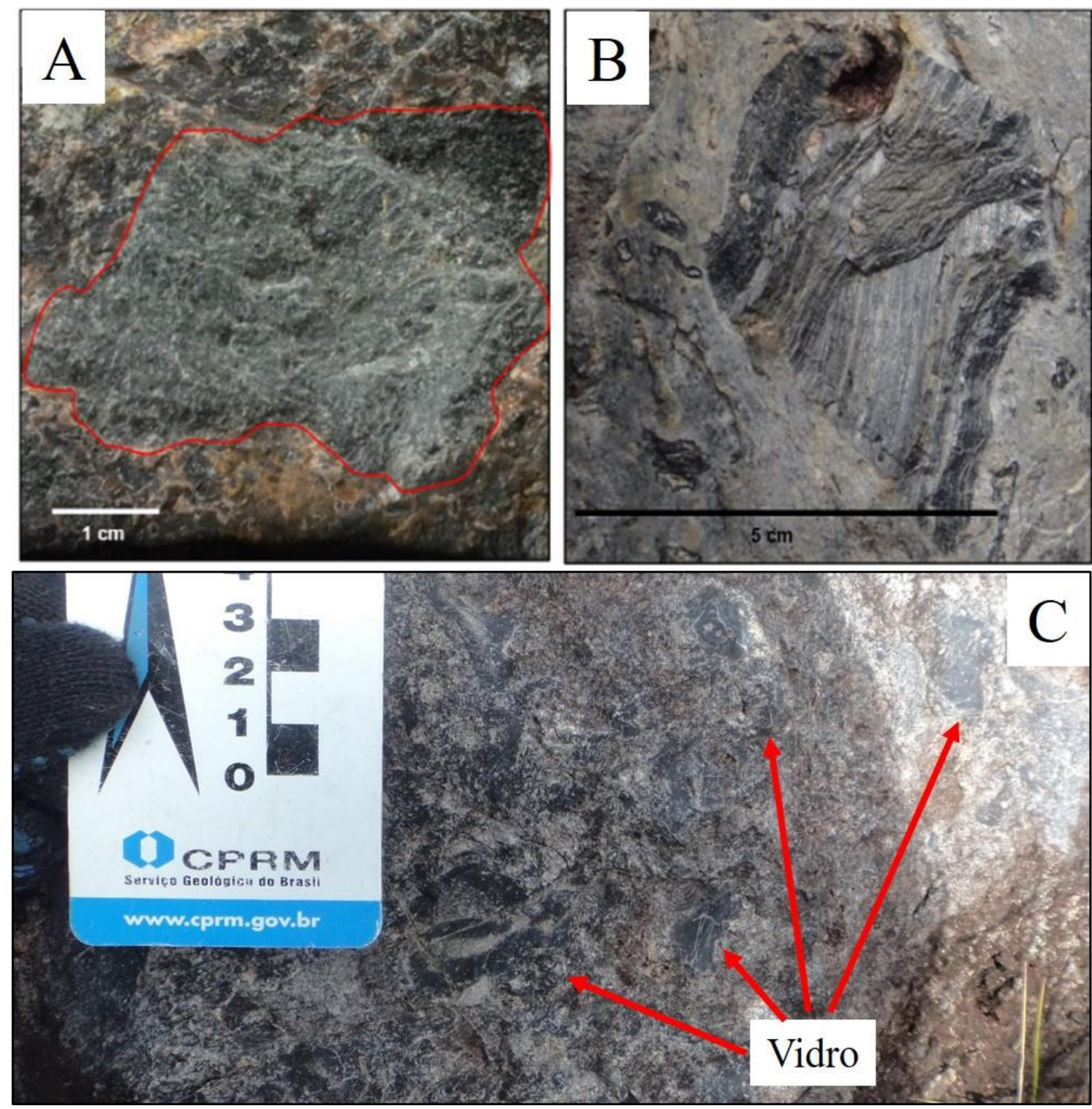

Figura 5 - A) Litoclasto máfico, afanítico, subanguloso, magnético em ignimbrito cinza rosado. B) Litoclasto anguloso com estrutura semelhante ao ignimbrito que exibe deformação. C) Fragmentos vítreos angulosos expostos em capa intempérica.

\section{Aspectos microscópicos}

Todas as rochas ignimbríticas exibem ao microscópio moderado a alto grau de soldamento evidenciado pela presença comum de textura eutaxítica com formação de finos fiammes de cor escura que contornam os fragmentos existentes. Texturas fluidal (Fig. 6A), vitrofírica (Fig. 6B), esferulítica (Fig. 6C), seriada e poiquilítica também são observadas.

A partir de aspectos composicionais e texturais foi possível individualizar três grupos principais de ignimbritos: maciços, reomórficos e os que exibem grau moderado de soldamento.

Os ignimbritos maciços, apresentam moderado grau de soldamento, rara textura eutaxítica, variação na proporção de cristaloclastos e vesículas preenchidas por quartzo e feldspato (Fig. 6D). Por outro lado, os reomórficos são criptocristalinos e refletem o mais alto grau de soldamento e deformação, com formação de dobras (Fig. 6E). Raros cristais de quartzo são observados e ocorrem de forma dispersa. Os ignimbritos moderamente soldados 
apresentam altas quantidades e imensa variação nos tamanhos de fragmentos de cristais, rochas, vidro, além de porções vítreas intensamente devitrificadas evidenciadas por textura esferulítica (Fig. 6F).
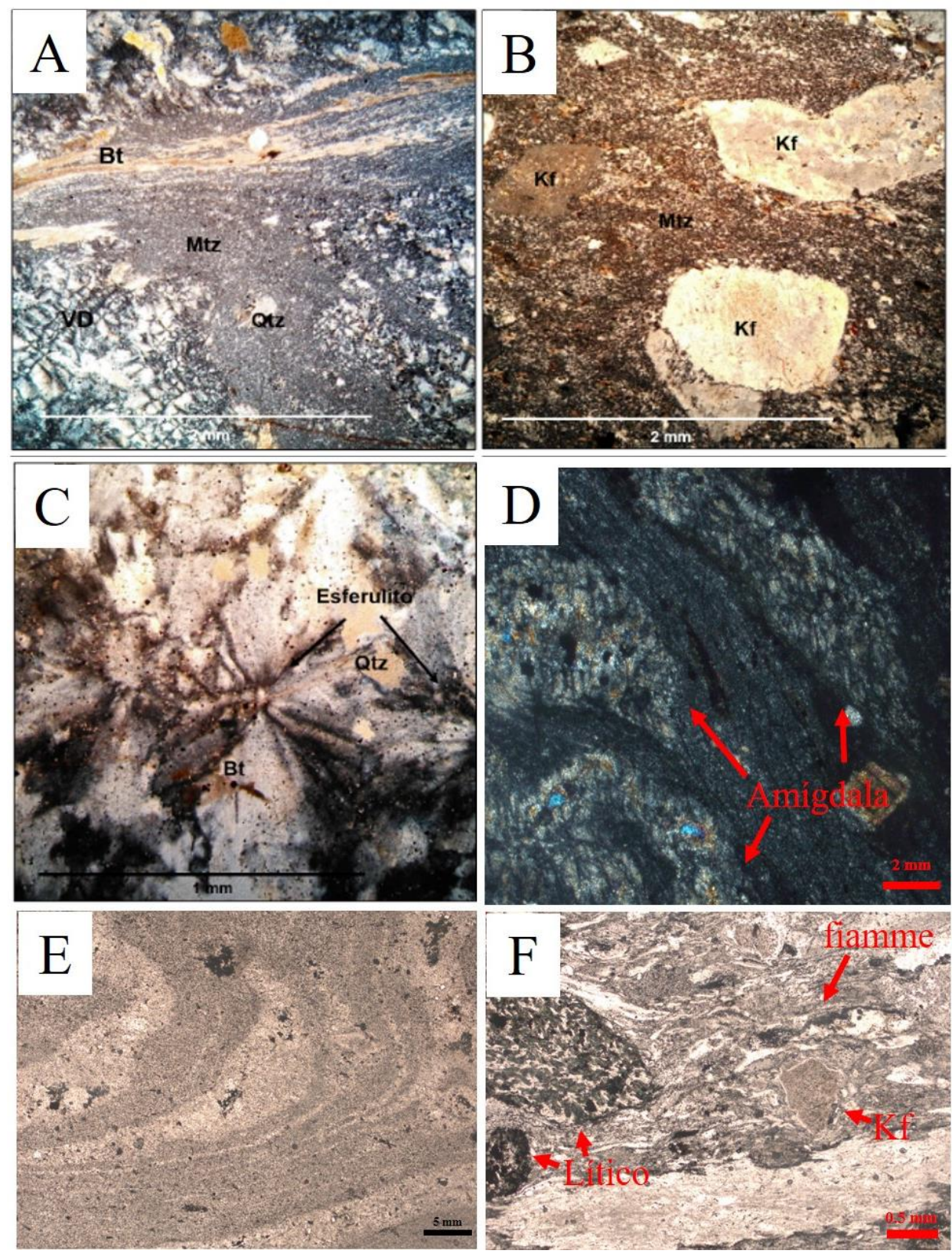

Figura 6 - A) Textural fluidal evidenciada pelas finas palhetas orientadas de muscovita em ignimbrito de moderado soldamento. PC B) Textura vitrofírica e cristaloclastos de feldspato alcalino em ignimbrito sem estruturação. PC. C) Textura esferulítica com cristais de quartzo e biotita nas proximidades em ignimbrito de soldagem moderada. PC. D) Amígdalas alongadas preenchidas por uma mistura de quartzo e feldspatos em ignimbrito de moderado soldamento. PC. E) Ignimbrito reomórfico exibindo alto grau de soldamento e deformação. PP. F) Relação entre os piroclastos do ignimbrito de soldagem moderada. PP: Polarizadores Paralelos; PC: Polarizadores Cruzados; Mtz: Matriz; VD: Vidro devitrificado; Qtz: Quartzo; Kf: Feldspato alcalino; Bt: Biotita. 
De modo geral, os cristais representam o tipo de fragmento mais abundante nestas rochas. São cristais de sanidina, quartzo e plagioclásio, além de biotita e \pm hornblenda. Os cristaloclastos estão dispersos em matriz vitrofírica e encontram-se geralmente com golfos de corrosão, denteados e bastante sericitizados e/ou saussuritizados. Como acessório tem-se zircão, pirita, magnetita, e \pm epidoto. Os cristais de zircão eventualmente manifestam halos pleocróicos. Os constituintes secundários são principalmente sericita, epidoto e carbonato, ocorrendo ainda clorita, muscovita, \pm argilomineral e \pm titanita.

Os cristais de sanidina são tabulares, subédricos de até $2 \mathrm{~mm}$ e também são um importante constituinte da matriz, onde exibem faces anédricas. Em geral mostram geminações Carlsbad, corrosão nas bordas e intensa sericitização. Alteração para muscovita também ocorre, sendo mais comum em porções intensamente alterada da rocha. Nesses locais formam agregados com plagioclásio, magnetitas e cloritas ripiformes que por vezes encontram-se orientadas, além de cristais anédricos de biotita-

O plagioclásio é tabular e pode chegar a mais de $2,5 \mathrm{~mm}$, como por vezes observados nos ignimbritos de soldamento moderado. De modo geral encontra-se alterado para sericita, além de epidoto, carbonato e \pm muscovita. Exibem geminação polissintética e subordinadamente Carlsbad, que podem ocorrer bem preservadas ou apenas como vestígios, devido aos intensos processos de alteração, onde nota-se bordas corroídas e embaiadas (Fig. 7A). Textura poiquilítica com cristais angulosos de piritas e magnetitas, biotita e quartzo, também são observadas, além de sobrecrescimento.

O quartzo ocorre como cristaloclasto de até $2 \mathrm{~mm}$. Por vezes formam agregados granulares com carbonato na matriz ou são policristalinos, sendo frequente $\mathrm{O}$ preenchimento de fraturas (Fig. 7B). Geralmente apresentam-se embaiados e com golfos evidenciando intensa corrosão (Fig. 7C). Participa também como produto de devitrificação associado com feldspato alcalino ao qual, juntos, formam arranjos radiais aciculares exprimindo textura esferulítica. Ocorrem de forma abundante nos ignimbritos de soldamento moderado e ricos em piroclastos, mais precisamente em porções extremamente alteradas, em que são bordejados por plagioclásio, piritas, magnetitas e cloritas ripiformes que por vezes encontram-se orientadas

A actinolita é uma fase rara, encontrada principalmente nos ignimbritos pouco soldados, sendo por vezes o principal representante máfico. Preferencialmente são cristais subédricos, cujos aglomerados exibem orientação e apresentam formas aciculares

A biotita ocorre como minús-culos cristais anédricos disseminados em matriz vitrofírica, geralmente $<0,05 \mathrm{~mm}$. Como cristaloclastos, estes minerais são subédricos, lamelares por vezes com forma acicular, frequentemente corroídos. Alteração parcial ou total para clorita é comum em porções alteradas. Nestes locais mostram associação com piritas, magnetitas, moscovitas, quartzo e sanidina. Além de apresentarem inclusões de zircão com halos pleocróicos que exibem evidente alteração (Fig. 7D).

Cristais anédricos de zircão mal desenvolvidos e isolados, ocorrem dispersos na matriz e associados a vênulas. Piritas e magnetitas são abundantes e exibem hábito predominantemente euédrico, sendo comum tamanhos entre $0,03-0,05 \mathrm{~mm}$, raramente não estão oxidados. 
Cristais anédricos e intensamente fraturados de titanita ocorrem em contato com magnetitas.

Os litoclastos máficos são constituídos por fenocristais de plagioclásio e anfibólio aciculares; quartzo, biotita e magnetitas compõem a matriz. Epidoto granular e sericita ocorrem como produto de alteração do plagioclásio. Destaca-se a variação textural dos litoclastos máficos, onde muitas vezes só é possível diferenciar os fenocristais de plagioclásio (Fig. 7E).

Os púmices geralmente estão achatados e formam fiammes. Apenas nos ignimbritos de moderada soldagem exibem-se como fragmentos subangulosos e angulosos, com tamanhos de até $2,5 \mathrm{~mm}$ e formas lenticulares e alongados, assim como intensa alteração para filossilicatos. A ausência de porosidade, característica diagnóstica de púmice, pode ser explicada pelo grau de soldagem e idade das exposições. Uma vez que a textura eutaxítica reflete a diminuição da porosidade do depósito e ainda faz com que os púmices fiquem dispostos paralelos ao fluxo exibindo, geralmente, essas formas lentiformes.

Ressalta-se a ocorrência comum de vênulas paralelas e subparalelas, a textura eutaxítica de até $1 \mathrm{~mm}$, por vezes irregulares, cujos constituintes mineralógicos são essencialmente agregados de quartzo, opaco, carbonato, epidoto, raras biotitas, \pm muscovitas e \pm cloritas, podendo apresentar epídoto como principal constituinte (Fig. 7F). 

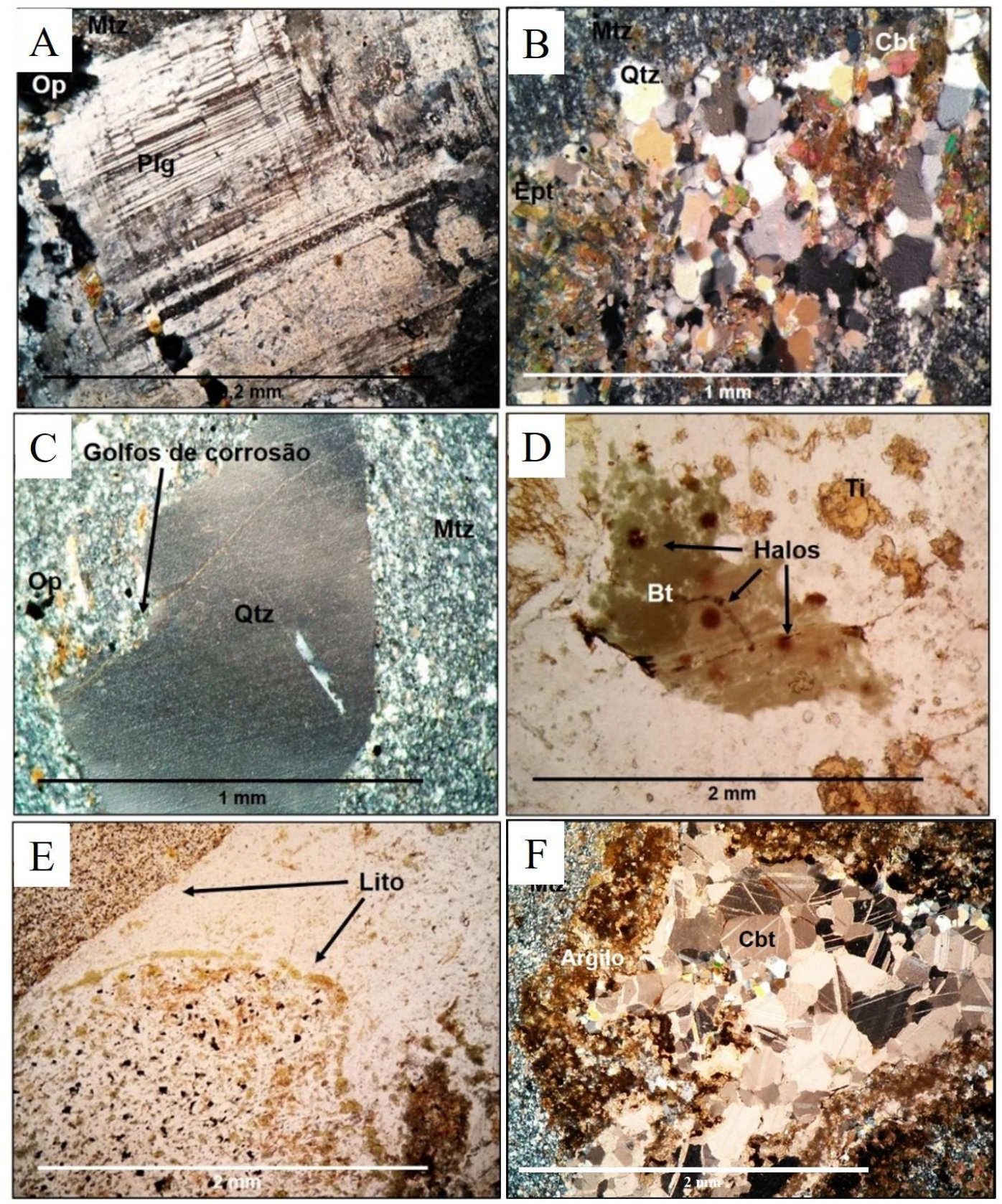

Figura 7 - A) Característico cristal de plagioclásio presente em todos os exemplares, maclas polissintéticas, intensa alteração e por vezes exibe sobrecrescimento. PC. B) Exemplificação da ocorrência comum de vênulas constituídas por associação de quartzo, epidoto, carbonato e feldspato alcalino. PC. C) Quartzo exibindo tamanho incomum dos que geralmente ocorrem nos ignimbritos estudados, com golfos de corrosão em meio matriz devitrificada. PC. D) Cristaloclasto de biotita com ocorrência isolada de halos pleocróicos ao redor de minúsculos cristais de zircão, inserida em porção preferencialmente carbonática. PP. E) Litoclastos predominantes das rochas ignimbríticas, destaca-se variação textural. PP. F) Ignimbritos moderadamente soldado com porções intensamente alteradas, destaque para os carbonatos maclados e argilominerais. PC. PP: Polarizadores Paralelos; PC: Polarizadores Cruzados; Plg: Plagioclásio; Mtz: Matriz; Lito: Litoclasto; Argilo: Argilomineral; Cbt: Carbonato; Ept: Epidoto; Qtz: Quartzo; Bt: Biotita; Ti: Titanita. 


\section{DISCUSSÕES E CONSIDE- RAÇÕES FINAIS}

Ainda que estas rochas estejam expostas preferencialmente sob a forma de blocos rolados e apresentem evidente variação em um mesmo afloramento quanto a proporção de cristaloclastos, litoclastos e vitroclastos, impedindo sua respectiva caracterização faciológica in situ, é possível distinguir duas variações diferenciadas por processos sin- e pósdeposicionais melhor observados nas investigações microscópicas.

Os principais processos sin- e pós-deposicionais identificados nos ignimbritos são a soldagem e a devitrificação. $O$ primeiro não ocorre de forma homogênea, mas é preferencialmente alto, sendo evidenciado pela presença de textura eutaxítica, marcada pelo achatamento de púmices que se encontram dispostos paralelos ao fluxo, assim como cristais e fragmentos líticos.

A presença de textura parataxítica nos ignimbritos reomórficos somados as estruturas dobradas e irregulares também podem ser explicadas pelo grau de soldamento. O processo reomórfico é capaz e de fazer com que estas rochas manifestem comportamento físico semelhante ao de derrames de lavas, no qual o fluxo seria constituído por partículas com baixa viscosidade facilitando a geração de deformações, embora processos de mistura de magmas também sejam mencionados (Branney \& Kokelaar, 1992; McPhie et al., 1993).

Os esferulitos refletem processos de devitrificação em vidro vulcânico, cuja morfologia relaciona-se diretamente a temperatura de formação, sendo a esférica a forma ocorrente nas rochas estudadas, tal textura consiste em arranjos fibrorradiados e indicam temperaturas em torno de $700{ }^{\circ} \mathrm{C}$ (Lofgren, 1971).

Os púmices em sua forma soldada ou não representam a parcela de piroclastos juvenis das amostras. Enquanto os litoclastos cognatos, definidos por Sommer et al. (2003) como aqueles clastos originados da fragmentação de rochas vulcânicas comagmáticas anteriormente formadas, correspondem, neste trabalho, aos fragmentos do reoignimbrito, cuja origem pode estar associada ao mesmo episódio vulcânico da rocha hospedeira ou representar um evento mais antigo

Os litoclastos máficos, magnéticos e abundantes nas três variações de ignimbritos, correspondem a fragmentos englobados aleatoriamente durante o transporte. Podem ser rochas do embasamento não aflorante, visto que não há registro em superfície de eventos básicos mais antigos ou de mesma idade que as rochas descritas. Por outro lado, os litoclastos microporfiríticos félsicos podem ser correlacionados aos granitos da Suíte Pedra Pintada, uma vez que estes são os únicos litotipos aflorantes na Folha Vila de Tepequém que exibem características similares. Destaca-se ainda que fragmentos líticos máficos semelhantes aos encontrados neste trabalho também são descritos em outras partes do Escudo das Guianas onde o vulcanismo Surumu foi cartografado.

As alterações mais frequentes nestas rochas são sericitização e saussuritização. A primeira é a principal responsável por substituir parcialmente ou totalmente os feldspatos. Enquanto a associação de sericita, epidoto, carbonato, \pm clorita e \pm argilomineral podem refletir hidrotermalismo regional de baixa temperatura já discutido na literatura para aquela porção da Folha Vila Tepequém (CPRM, 2010).

A partir da integração dos dados de campo e petrográficos foi possível empilhar os diferentes grupos de ignimbritos descritos e sugerir uma evolução do processo de soldagem desse fluxo piroclástico (Fig. 8A). 


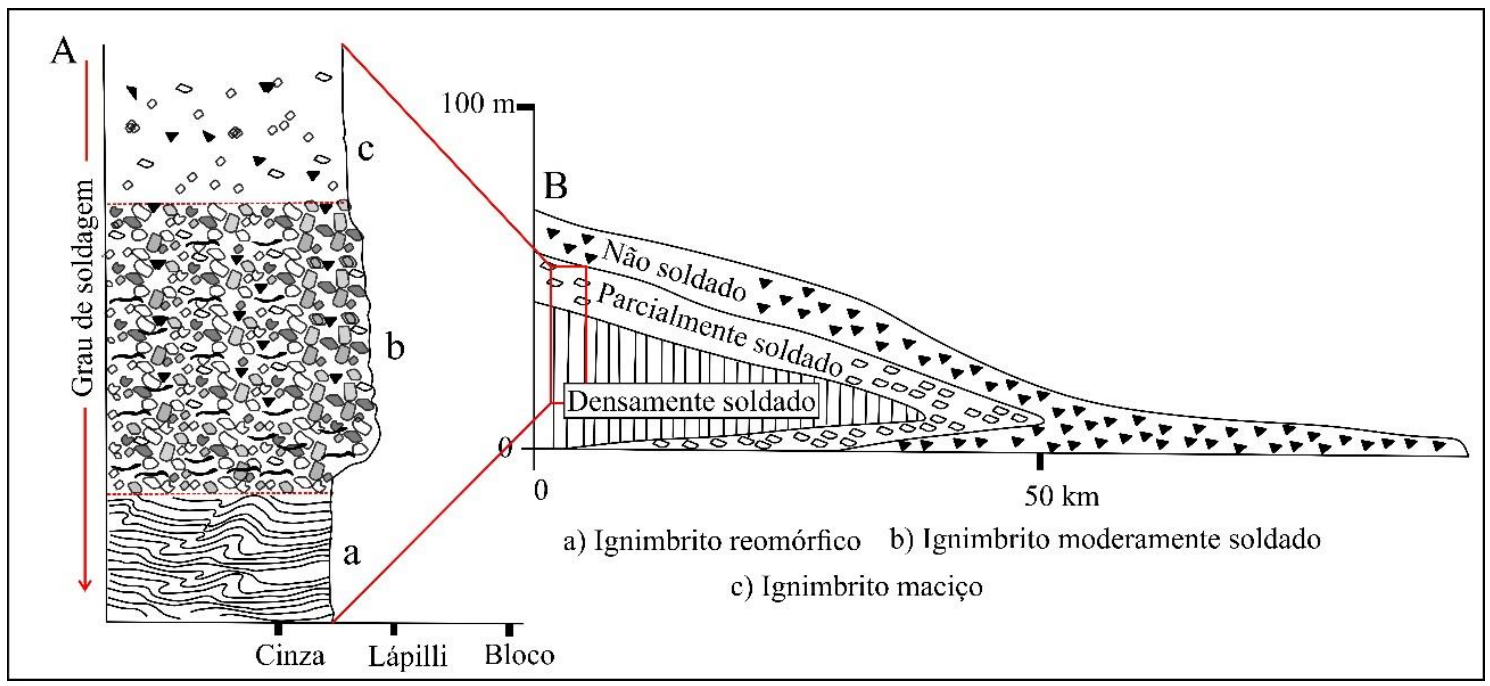

Figura 8 - A) Perfil estratigráfico esquemático mostrando a sucessão dos ignimbritos descritos na área de estudo a partir de informações de campo e petrografia. B) Variação lateral e vertical do grau de soldagem de acordo com sua progressão (McPhie et al., 1993).

As texturas eutaxítica e parataxítica são os principais indicativos do processo de soldagem e da sua progressão tanto na extensão como na espessura do depósito. Quando somados ao grau de achatamento dos piroclastos, por exemplo, facilitam a delimitação de distintas zonas.

Nos registros da Formação Cachoeira da Ilha, a correlação desses aspectos aponta para regiões inferiores a intermediárias, uma vez que o soldamento ocorre de forma desigual (Fig. 8B). Isso não significa necessariamente que temos a progressão de apenas um único fluxo piroclástico. Em consequência da idade proterozoica dos depósitos fica fácil imaginar múltiplos fluxos como outra possibilidade.

Por outro lado, a quantidade e diversidade de piroclastos observadas no ignimbrito de moderado grau de soldagem indicam áreas proximais a condutos vulcânicos, uma vez que ignimbritos ricos em fragmentos são fácies típicas desse contexto quando nos referimos a estratigrafia vulcânica, a probabilidade de termos um único fluxo se torna factível. Visto que quanto mais próximos mais espessos são os depósitos, favorecendo o registro da progressão do processo de soldagem de um episódio de fluxo piroclástico.

Por fim, em virtude da impossibilidade de descrição faciológica in situ não foi possível a caracterização completa da área estudada e a compreensão do vulcanismo que envolvem estas rochas. Para isso recomenda-se a realização de trabalhos de campo em escala de detalhe, estudos petrográficos, geoquímicos e geocronológicos nos litotipos da Formação Cachoeira da Ilha.

\section{Agradecimentos}

Os autores agradecem ao Departamento de Geologia, ao Laboratório de Ensino de Geociências e ao Laboratório de Petrologia do Instituto de Geociências da Universidade Federal de Roraima pela estrutura fornecida para a realização desta pesquisa.

\section{REFERÊNCIAS}

Bezerra, K.R.F. 2010. Caracterização geológica e geoquímica das rochas 
vulcânicas das serras do Tabaco e Tarame, NE de Roraima, Domínio Surumu, Cráton Amazônico. Dissertação de Mestrado, Universidade Federal do Amazonas, Brasil. 80 p.

Branney, M. J. \& Kokelaar, P. 1992. A Reappraisal of ignimbrite emplacement: progressive aggradation and changes from particulate to non-particulate flow during emplacement of highgrade ignimbrite.

Bulletin Volcanology, n. 54, p. 504-520.

CPRM - COMPANHIA DE PESQUISA DE RECURSOS MINERAIS SERVIÇO GEOLÓGICO DO BRASIL. 2010. Geologia e recursos minerais da Folha Vila de Tepequém - NA.20-X-A-LLL, Estado de Roraima, Escala 1:100.000. Manaus: Ministério de Minas e Energia / Secret. de Geologia, Mineração e Transformação Mineral /Serviço Geológico do Brasil, 175 p.

Fisher, R. V. 1966. Rocks composed of volcanic fragments. Earth Science Reviews. International Magazine for Geo-Scientists, v. 1, p. 287298.

Fraga, L.M.; Vazques, M.L.; Almeida, M.; Dreher, A.M.; Reis, N. 2017. A influência da orogenia eoorosiriana na formação da SLIP Uatumã, parte central do Cráton Amazônico. In: $15^{\circ}$ Simpósio de geologia da Amazônia, 2017, Belém, Pará (Extended Abstracts) p. 405-408.

Gibbs, A.K.; Barron, C.N. 1993. The Geology of the Guiana Shield. New York, Claredon Press, Oxford, $245 \mathrm{p}$.

Le maitre, R. W. 2002. Igneous rocks: A classification and glossary of terms. 2. ed. Cambridge: University Press, $232 \mathrm{p}$.
Lofgren, G. 1971. Spherulitic textures in glassy and crystalline rocks. $J$ Geophys Res., v. 76, p. 5635-5648.

McPhie, J.; Doyle, M.; Allen, R. 1993. Volcanic Textures. A Guide to the interpretation of textures in volcanic rocks. University of Tasmania, Australia, 198 p.

Reis, N.J.; Fraga, L.M.B. 1998. Geologia do Estado de Roraima. Publicação Interna, Inédito, CPRM, Manaus, $24 \mathrm{p}$.

Reis, N.J.; Fraga, L.M.; Faria, M.S.G.; Almeida, M.E. 2003. Geologia do Estado de Roraima. Géologie de la France, 2 (3): 121-134.

Reis, N.J., Faria, M.S.G., Almeida, M.E., Oliveira, M.A. 2004. Folhas NA.20-Boa Vista e NB.20Roraima. In: Carta geológica do Brasil ao milionésimo, Sistema de Informações Geográficas-SIG, folhas na escala de 1: 1.000.000, Schobbenhaus, C., Gonçalves, J.H., Santos, J.O.S., Abram, M.B., Leão Neto, R., Matos, G.M.M., Vidotti, R.M., Ramos, M.A.B., Jesus, J.D.A., editores. CPRM, Brasília, CD-ROM.

Reis, N.J.; Nadeau, S.; Fraga, L.M.; Betiollo, L.M.; Faraco, M.T.L.; Reece, J.; Lachhman, D.; Ault, R. 2017. Stratigraphy of the Roraima Supergroup along the Brazil-Guyana border in the Guiana shield, Northern Amazonian Craton - results of the Brazil-Guyana Geology and Geodiversity Mapping Project. Brazilian Journal of Geology, 47(1): 43-57. DOI: 10.1590/2317-4889201720160139

Santos, J.O.S. 2003. Geotectônica do Escudo das Guianas e BrasilCentral. In: Geologia, Tectônica e Recursos Minerais do Brasil, Bizzi, L.A., Schobbenhaus, C., Vidotti, R.M., Gonçalves, J.H. editores. CPRM, Brasília, p. 169226. 
Schmid, R. 1981. Descriptive nomenclature and classification of pyroclastic deposits and fragments: Recommendations of the IUGS Subcommision on the Systematics of Igneous Rocks. Geology, v. 9, p. 41- 43.

Sommer, C. A.; Lima, E. F.; Nardi, L. V. S.; Liz, J. D.; Pierosan, R. 2003. Depósitos de fluxo piroclástico primários: caracterização e estudo de um caso no vulcanismo ácido Neoproterozoico do escudo Sulrio-grandense. Pesquisas em Geociências, v. 30, n. 1, p. 3-26.
Viana, K. L. G. 2012. Petrologia do magmatismo Aricamã na região da Vila do Tepequém (RR), Domínio Urariquera Cráton Amazônico. Faculdade de Geologia, Universidade Federal do Amazonas, Dissertação de Mestrado, Universidade Federal do Amazonas, 98 p. 